Check for updates

Cite this: RSC Adv., 2017, 7, 42443

Received 15th June 2017

Accepted 24th August 2017

DOI: $10.1039 / c 7 r a 06672 d$

rsc.li/rsc-advances

\section{Design of micro-shell $\mathrm{Cu}-\mathrm{Al}$ porous ceramometals as catalysts for the water-gas shift reaction}

\author{
S. Tikhov, (D) *a T. Minyukova, ${ }^{a}$ K. Valeev, ${ }^{a}$ S. Cherepanova, ${ }^{a}$ A. Salanov, ${ }^{a}$ \\ V. Kaichev, (D) ab A. Saraev, ${ }^{\text {ab }}$ A. Andreev, (D) ${ }^{a}$ O. Lapina ${ }^{\mathrm{ab}}$ and V. Sadykov ${ }^{\mathrm{ab}}$
}

XRD, NMR, SEM with mapping, and XPS were used to examine the structure and microstructure of porous ceramometals, CuAlO/CuAl, synthesized by mechanochemical alloying of a mixture of $\mathrm{Cu}+\mathrm{Al}(\mathrm{Cu}: \mathrm{Al}=$ $87: 13$ wt\%) followed by hydrothermal treatment and heat treatment in air. The egg-shell nature of the microstructure was revealed: the metallic cores consisting of copper and aluminum alloys are surrounded by the oxide matrix containing copper oxides and X-ray amorphous mixed oxides of copper and aluminum. Catalytic activity of ceramometals in the water-gas shift reaction (WGSR) estimated for their fine fractions at $240{ }^{\circ} \mathrm{C}$ and expressed as efficient first-order rate constants is lower than that of a CuZnAl oxide catalyst due to the lower (approximately by an order of magnitude) specific surface area of the ceramometals. The specific activity of ceramometals expressed as the specific rate constant related to the unit surface area of metallic copper exceeds that for the CuZnAl oxide catalyst and correlates with the content of crystallized intermetallics. Mechanical, textural and thermophysical properties of ceramometals were assessed. The presence of ultramacropores with sizes up to tens of microns was shown to be typical for ceramometals. As a result, the activity of granulated ceramometal catalysts in the WGSR, due to a high diffusion permeability, is comparable with that of granulated CuZnAl oxide. A mild leaching substantially increases the activity of cermet granules.

\section{Introduction}

The water-gas shift reaction (WGSR) is one of the primary industrial steps of hydrogen production. In recent decades, many works devoted to kinetics and properties of catalysts for this process have been published ${ }^{1-5}$ and summarized in a series of reviews. ${ }^{6-9}$ These catalysts are usually comprised of $\mathrm{Cu}, \mathrm{Zn}$ and $\mathrm{Al}$ oxide composites prepared by coprecipitation or impregnation. Among the key properties of a catalyst (support) for WGSR is its ability to ensure a high dispersion of copper. According to data reported in ref. 2, specific activity of metallic copper in the WGS remains nearly constant in a broad range of dispersions, while structure sensitivity is claimed in other works. ${ }^{1}$ Hence, variation of conditions of catalytic testing makes it difficult to compare the results. Another main problem of the low temperature WGSR reaction is a low activity of the conventional granulated CuZnAl catalyst per the unit volume of the catalyst bed ${ }^{8-10}$ explained by a low loading density and poor access of reagents into the bulk of granules with a low porosity. A possible way to increase such a volume activity is the use of ceramometal catalysts with enhanced real and loading density possessing also a developed system of transport macropores

${ }^{a}$ Boreskov Institute of Catalysis SB RAS, Lavrentieva Ave., 5, 630090 Novosibirsk, Russia.E-mail: tikhov@catalysis.ru

${ }^{b}$ Novosibirsk State University, Pirogova Str., 2, 630090 Novosibirsk, Russia and mesopores. Such catalysts could also prevent emergence of temperature gradients within the catalytic layer due to a high thermal conductivity provided by the presence of metal particles in their bulk. Cermet catalysts synthesized from $\mathrm{Al}-\mathrm{Cu}-\mathrm{Fe}$ alloys were applied earlier for the steam reforming of methanol. ${ }^{11,12}$ These catalysts possess a complex microstructure comprised of the metal cores surrounded by the oxidic shell with segregated nanoparticles of metallic $\mathrm{Cu}$. The specific activity of copper was found to change non-monotonously with its dispersion. ${ }^{11}$ The aim of the present work was development and detailed characterization of a new ceramometal CuAlO/ $\mathrm{CuAl}$ catalyst prepared through the step of mechanical alloying of $\mathrm{Cu}-\mathrm{Al}$ powders. Main characteristics of these catalysts precursors were reported in the previous work. ${ }^{13}$

\section{Experimental}

\subsection{Preparation}

Aluminum powder (PAP-2, GOST 5494-95, Russia) with plateletshaped particles (typical sizes 10/40 microns) and electrolytic copper powder (PMS-1, GOST 4960-75, Russia) of dendritic shape were used as starting materials.

(a) Mechanical activation (MA) of the mixture containing (wt\%) ${ }^{87} \mathrm{Cu}+{ }^{13} \mathrm{Al}$ was used to synthesize the powdered precursor. MA was carried out in a high-power planetary ball mill APF (the diameter of milling steel balls $5 \mathrm{~mm}$; ball-to- 
powder mass ratio $8: 1$; powder weight $100 \mathrm{~g}$; balls acceleration $65 \mathrm{~g})$. The activation time was 3-12 $\mathrm{min}$. The increase of MA time decreases the average particle size and increases the alloying degree. The vials and milling balls were made of steel. The volume of the milling vial was $1 \mathrm{~L}$. The content of Fe incorporated into the powder mixtures as contamination was very low $(0.14$ ry0.02 $\mathrm{wt} \%)$. To prevent sticking of the powder to balls and vial walls, ethanol was used as a process control agent. It was added into the vial at $30 \mathrm{~s}$ before the start of milling.

(b) The product of mechanical activation was loaded into a stainless steel die specially designed to ensure a free access of water and hydrogen release. Variation of the internal shape of the die where a powder was loaded provides a broad variation of the shape of monoliths.

(c) For the hydrothermal treatment (HTT), the loaded die was placed into the vessel with boiling water and kept there for five hours. This step provides formation of strong monoliths due to conjugation of the red-ox reaction of aluminum oxidation and creation of contacts between the particles due to generation of aluminum hydroxides. Similar to the MA step, oxidation of $\mathrm{Al}$ at the HTT step diminishes the extent of the exothermic reaction of $\mathrm{Me}-\mathrm{Al}$ interaction with air at the calcination step.

(d) The monolithic product of HTT was removed from the die, dried for 1 hour at $120{ }^{\circ} \mathrm{C}$ and calcined under air at $550{ }^{\circ} \mathrm{C}$. This yields a mechanically strong material and develops the mesoporous structure of cermets. The density of granules increased with decreasing the time of mechanical activation from 3.87 (12 $\mathrm{min}$ ) to $4.24 \mathrm{~g} \mathrm{~cm}^{-3}$ ( $3 \mathrm{~min}$ ).

The reference sample was represented by the CuZnAl bulk oxide catalyst (similar to the commercial one) synthesized by the heat treatment of mixed $\mathrm{Cu}-\mathrm{Zn}-\mathrm{Al}$ hydroxide (CZA). The hydroxide was obtained via coprecipitation from $10 \%$ aqueous solutions of metal nitrates by a sodium carbonate solution with subsequent washing and drying according to the procedure reported in a patent. ${ }^{\mathbf{1 4}}$

\subsection{Characteristics of samples}

X-ray diffraction (XRD) patterns of powders were recorded by means of a D8 Advance powder diffractometer (Bruker AXS) equipped with a one-dimensional Lynx-Eye detector using $\mathrm{Cu}$ $\mathrm{K} \alpha$ radiation. XRD patterns were recorded in the $2 \theta$ range $15-95^{\circ}$ with a step of $0.05^{\circ}$ and a counting time of $3 \mathrm{~s}$ per step. The quantitative analysis was carried out using Rietveld refinement in TOPAS software (Bruker AXS GmbH). The average size of the crystallites was also determined using TOPAS taking into account the instrumental peak broadening. The instrumental peak broadening was determined from the XRD pattern of a reference sample (SRM676, corundum) by the approximation method using a convolution of Lorentzian and Gaussian functions. The aluminum content in $\mathrm{Cu}_{1-x} \mathrm{Al}_{x}$ solid solutions was calculated using Vegard's law.

Scanning electron microscopy (SEM) studies of powders were performed on a JSM 6460SV microscope (JEOL Ltd.) equipped with an energy-dispersive spectroscopy unit EDX INCA (Oxford Inst.). Samples for these studies were prepared either by spreading the powders over a substrate or by fixing particles in an organic binder followed by polishing. The latter technique allowed to study the microstructure of the powder particles. Transmission electron microscopy (TEM) studies of powders were carried out using JEM-2010 and JEM-2200FS (JEOL Ltd.) microscopes; High-Angle Annular Dark Field Scanning Transmission Electron Mode (HAADF STEM) and Energy Dispersive X-ray Spectroscopy (EDX) were utilized. The EDX in the STEM mode was used for the elemental mapping of samples by $\mathrm{Al} \mathrm{K}(E=1.486 \mathrm{keV})$ and $\mathrm{Cu} \mathrm{K}(E=8.040 \mathrm{keV})$ radiation and semi-quantitative analysis of areas as small as $1 \mathrm{~nm}$ in diameter. To prepare samples for TEM studies, powders were dispersed in ethanol and suspensions were subjected to ultrasonic treatment at $35 \mathrm{kHz}$. The suspension was poured onto a holey carbon substrate on a Mo grid and dried at $20{ }^{\circ} \mathrm{C}$.

Al NMR experiments were carried out on a Bruker Avance 400 MHz spectrometer with a magnetic field of $9.4 \mathrm{~T}$. Spectra were recorded at resonance frequencies of ${ }^{27} \mathrm{Al}$ and ${ }^{63} \mathrm{Cu}$ in this magnetic field, i.e. 104.31 and 106.12 MHz, respectively. Due to rather broad resonance lines and experimental dead time, the spectra were acquired by spin echo technique with two equivalent pulses p1 $-\tau-\mathrm{p} 1-\tau$. The pulse duration p1 of ${ }^{27} \mathrm{Al}$ NMR experiments was $0.5 \mu \mathrm{s}(\pi / 8)$, and for ${ }^{63} \mathrm{Cu}$ NMR spectra p1 was 1 $\mu \mathrm{s}(\pi / 6)$. The interpulse delay $\tau$ was $15 \mu$ s for static experiments, and it was synchronized with the sample spinning rate in MAS (magic angle spinning) experiments. The experiments were carried out with different MAS probes of 4, 2.5 and $1.3 \mathrm{~mm}$ outer rotor diameter providing sample rotation at 15, 30, and $60 \mathrm{kHz}$. The static spectra were obtained with the $4 \mathrm{~mm}$ probe. The spectral width used in experiments was $5 \mathrm{MHz}$, and the sequence repetition delay varied from 0.1 to $2 \mathrm{~s}$ since all samples contained intermetallic and paramagnetic compounds which decrease $T_{1}$ relaxation times. The chemical shifts were externally referenced to diluted $\mathrm{Al}(\mathrm{OH})_{6}{ }^{3+}$ at $0 \mathrm{ppm}$ in ${ }^{27} \mathrm{Al}$ experiments, and to copper wire at 2396 ppm. ${ }^{15-17}$ The decomposition of static spectra was done on Lorentzian and Gaussian lines to obtain the best fit.

The chemical analysis of the catalyst surface was carried out using X-ray photoelectron spectroscopy (XPS). The XPS measurements were performed on a SPECS's Surface Nano Analysis $\mathrm{GmbH}$ (Germany) photoelectron spectrometer equipped with a PHOIBOS-150-MCD-9 hemispherical electron energy analyzer, a FOCUS-500 X-ray monochromator, and an XR-50M $\mathrm{X}$-ray source with a double $\mathrm{Al} / \mathrm{Ag}$ anode. The spectrometer was also equipped with a high-pressure cell (HPC), which enables heating samples before analysis in gaseous mixtures at pressures up to $0.5 \mathrm{MPa}^{18}$ The core-level spectra were obtained using the monochromatic AlK $\alpha$ radiation $(h \nu=1486.74 \mathrm{eV})$ under ultrahigh vacuum conditions. The charge correction was performed by setting the $\mathrm{Al} 2 \mathrm{p}$ peak at $74.5 \mathrm{eV}$ corresponding to aluminum in $\mathrm{Al}_{2} \mathrm{O}_{3}$. Before the XPS analysis, the catalysts were treated in 1 bar $\mathrm{O}_{2}$ at $270{ }^{\circ} \mathrm{C}$ for $1 \mathrm{~h}$ in HPC. After treatment of samples in the HPC the intensity of $\mathrm{C} 1 \mathrm{~s}$ peak was very low, which did not allow this peak to be used for calibration of the binding energy scale. Relative element concentrations were determined from the integral intensities of XPS peaks using the cross-sections according to Scofield. ${ }^{19}$ For detailed analysis, the spectra were fitted into several peaks after the background 
subtraction by the Shirley method. All the spectra were analyzed using the CasaXPS software. ${ }^{18}$ The line shape used for fitting the $\mathrm{Al} 2 \mathrm{p}$ and $\mathrm{Cu} 3 \mathrm{p}$ spectra was the product of Lorentzian and Gaussian functions. An asymmetric, so-called "LF" line shape was used for approximation of the $\mathrm{Cu} 2 \mathrm{p}_{3 / 2}$ spectra of copper. ${ }^{20}$ Note that the asymptotic form of the LF line shape is equivalent to the asymptotic form of the theoretical Doniach-Sunjic asymmetric line shape. However, this new line shape describes the asymmetric XPS peak more correctly than the conventional Doniach-Sunjic function does because the LF function is finite. After the XPS analysis of the oxidized samples, the catalysts were treated in 1 bar $\mathrm{H}_{2}$ at $270{ }^{\circ} \mathrm{C}$ for $1 \mathrm{~h}$, and the XPS analysis of the reduced catalysts was carried out. XPS data were used to estimate the surface concentration of copper $\left(\Theta_{\mathrm{Cu}}=\mathrm{Cu} /(\mathrm{Cu}+\mathrm{Al})\right)$ and the surface area of metallic copper $S_{\mathrm{Cu}}$ $\approx S_{\mathrm{BET}} \cdot \Theta_{\mathrm{Cu}}$.

The macropore volume was assessed from the difference between the volumes of micro/mesopores and the total pore volume. The total pore volume of the monolith was estimated from the values of true and apparent densities. True density was measured using a helium pycnometer - Autopycnometer 1320 (Micromeritics). The fraction of micropores and mesopores (called for brevity the "mesopores) as well as the specific surface area (SSA) were determined from adsorption isotherms of nitrogen recorded at $77 \mathrm{~K}$ using an ASAP-2400 Micromeritics instrument. The macropore volume was estimated from the difference of the total and mesopore volume.

Mechanical properties (compressive strength) were estimated as the limiting pressure that can be applied to the circle side of cylindrical pellets or granules before its destruction. ${ }^{21,22}$ Thermal expansion coefficient was measured on a DIL-402C (Netzsch) horizontal dilatometer. Samples were examined as prisms with a section of $6 \times 6 \mathrm{~mm}^{2}$ and a length of $10 \mathrm{~mm}$ in the range from 50 to $500{ }^{\circ} \mathrm{C}$ in air at a heating rate of $2^{\circ} \mathrm{min}^{-1}$.

Catalytic properties in WGSR were studied in a laboratory flow setup with the gas chromatographic analysis of the reaction mixture under the same conditions as earlier used for studies of the commercial $\mathrm{Cu}-\mathrm{Zn}-\mathrm{Al}-\mathrm{O}$ catalyst. ${ }^{9}$ The catalysts were activated in the mixture of $5 \% \mathrm{H}_{2}$ in $\mathrm{He}$ at $3000-4000 \mathrm{~h}^{-1}$ with a temperature ramp of $2^{\circ} \min ^{-1}$ up to $270{ }^{\circ} \mathrm{C}$ for $2 \mathrm{~h}$. Activity was measured at a pressure of 1 bar in the mixture of $\mathrm{CO}: \mathrm{H}_{2} \mathrm{O}: \mathrm{H}_{2}=8: 42: 50$ at a steam/gas ratio of 0.6-0.7; a catalyst $(0.14-0.25 \mathrm{~mm}$ fraction) mixed with quartz sand of the same particle size was used. The height of the catalyst bed diluted with quartz was $3 \mathrm{~cm}$, and the reactor diameter was $20 \mathrm{~mm}$. The temperature was continuously controlled with the aid of a thermocouple placed in a pocket of the reactor at the center of the catalyst bed. Catalyst was characterized by the apparent rate constant of the forward reaction, which was determined taking into account the reversibility of the reaction in an approximation of the first order with respect to $\mathrm{CO}$. The reaction rate constant was calculated under the assumption that the reactor operated in the plug flow regime. All catalytic data are given for the catalysts that reached a steady state activity (after continuous operation for at least $25 \mathrm{~h}$ ). The bulk density of the fraction of catalysts without quartz varied from 1 to $2.3 \mathrm{~g} \mathrm{~cm}^{-3}$. Activity of granules having a prismatic shape and dimensions $3.2 \times 3.2 \times 5 \mathrm{~mm}^{3}$ was also studied in the special Temkin single-row reactor. ${ }^{23}$ Due to a considerable variation of the bulk density at close weights, contact time also changed significantly, from 0.02 to $0.05 \mathrm{~s}$. Thermal stability $\left(k_{\mathrm{stab}}\right)$ was estimated from the ratio of $k$ at $240{ }^{\circ} \mathrm{C}$ after $20 \mathrm{~h}$ of operation to the initial $k$ (without overheat).

\section{Results and discussion}

\subsection{Phase composition according to XRD and NMR data}

3.1.1. XRD. According to XRD (Fig. 1), ceramometals contain a solid solution of aluminum in copper and an intermetallic, with the solid solution being the dominant phase, as seen from the intensities. The copper oxide phase was observed in all tested samples while separate phases of aluminum or aluminum oxide were not detected. Traces of a well crystallized phase with the interplanar distances of 3.37, 2.75, 2.46, 2.23 and $2.06 \AA$ not found in the PDF database (see an inset in Fig. 1) were detected. The most likely this phase belongs to an unknown intermetallic structure.

Table 1 lists qualitative and quantitative results of XRD phase analysis of ceramometals corresponding to diffraction patterns in Fig. 1. The new phase is not presented in Table 1 because it has a low (ca. $1 \mathrm{wt} \%)$ concentration.

As seen in Table 1 , the concentration of $\mathrm{Al}_{4} \mathrm{Cu}_{9}$ intermetallic goes through the maximum with increasing the time of preliminary MA of the copper-aluminum powder. Such changes in the intermetallic concentration were observed earlier by XRD

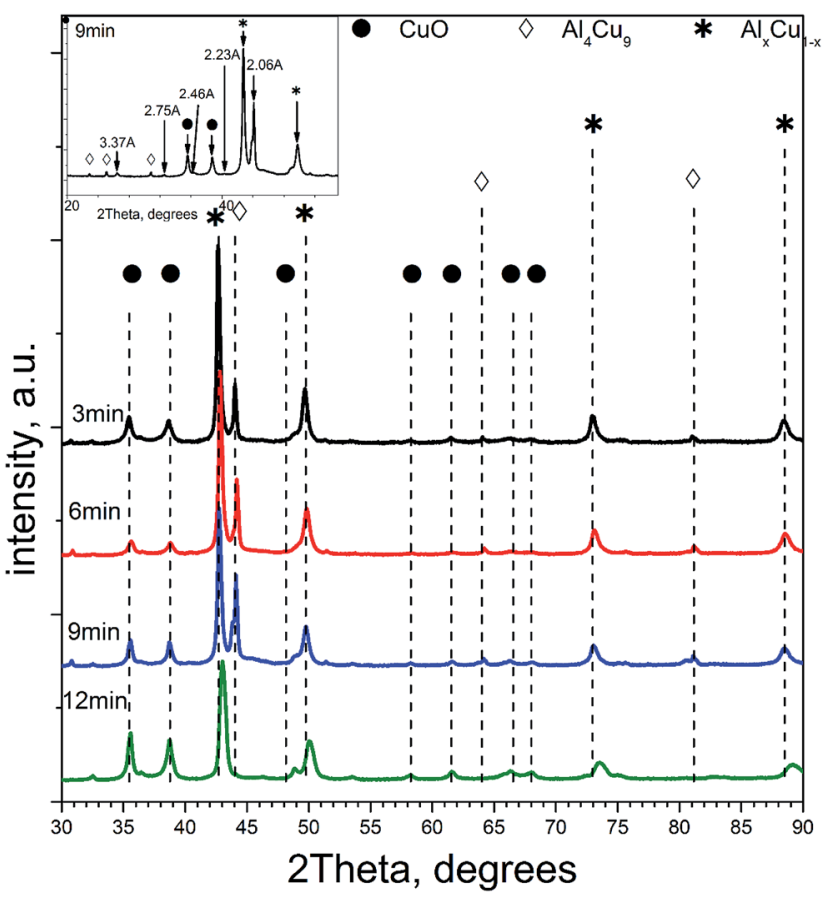

Fig. 1 Diffraction patterns of ceramometals at different MA times. Symbols denote peaks corresponding to the following phases: * a solid solution of aluminum in copper, $\mathrm{Al}_{x} \mathrm{Cu}_{1}, \diamond-\mathrm{Al}_{4} \mathrm{Cu}_{9}$ intermetallic [24-0003], - CuO [05-0661]. The inset displays a fragment of the diffraction pattern of the new phase. 
Table 1 XRD phase analysis of ceramometals, wt\%

\begin{tabular}{lllll}
\hline & $3 \mathrm{~min}$ & $6 \mathrm{~min}$ & $9 \mathrm{~min}$ & \multicolumn{1}{c}{$12 \mathrm{~min}$} \\
\hline $\mathrm{Cu}_{1-x} \mathrm{Al}_{x}$ solid solution & $49 \%(x=0.14)$ & $62 \%(x=0.10)$ & $48 \%(x=0.12)$ & $53.0 \%(x=0.06)$ \\
$\mathrm{Al}_{4} \mathrm{Cu}_{9}$ intermetallic & $12 \%$ & $20 \%$ & $27 \%$ & $0 \%$ \\
$\mathrm{CuO}$ & $39 \%$ & $18 \%$ & $25 \%$ & $47 \%$ \\
\hline
\end{tabular}

for the MA products ${ }^{13}$ that were further used as precursors for the synthesis of cermets. A similar trend is typical also for other MA conditions for CuAl-containing systems. ${ }^{24,25}$ The concentration of the solid solution is nearly constant, except for the sample activated $6 \mathrm{~min}$. The concentration of aluminum in the solid solution decreases monotonically with the time of activation (excluding 6 min point), while $\mathrm{CuO}$ concentration goes through the minimum. Remarkable is the absence of crystallized forms of mixed copper-aluminum oxides of the spinel type. It should be noted that XRD could not detect X-ray amorphous components in cermets as well as in MA products. $^{\mathbf{1 2 1 3}}$ Hence, variation of the content of aluminumcontaining components in the X-ray amorphous state could not be followed by this method.
3.1.2. ${ }^{27}$ Al NMR. Static spin echo ${ }^{27} \mathrm{Al}$ NMR spectra of cermets are displayed in Fig. 2a. An example of the spectrum deconvolution is shown in Fig. 3. The static ${ }^{27} \mathrm{Al}$ NMR spectra exhibit four main lines corresponding to different $\mathrm{Al}$ environments. The "aluminum oxide" $\left(\mathrm{Al}^{3+}\right)$ is centered at $\sim 0 \mathrm{ppm}$. The rest spectral lines are shifted due to the so-called Knight shift, ${ }^{\mathbf{1 6}}$ which is caused by a local field created by the conduction electrons on the nuclei.

As follows from our previous study of ball milled source precursors, ${ }^{13}$ lines at $\sim 870$ and $\sim 590$ ppm can be related to $\mathrm{Al}_{4} \mathrm{Cu}_{9}$ intermetallic compound, which for cermet are located at 1000 and 600 ppm (Fig. 2a). The line at $\sim 1400 \mathrm{ppm}$ is assigned to $\mathrm{Cu}_{1-x} \mathrm{Al}_{x}$ solid solutions with various stoichiometry. ${ }^{13,17}$ Therefore, these results are in the qualitative agreement with XRD data, while aluminum oxide is detected only by NMR. Due

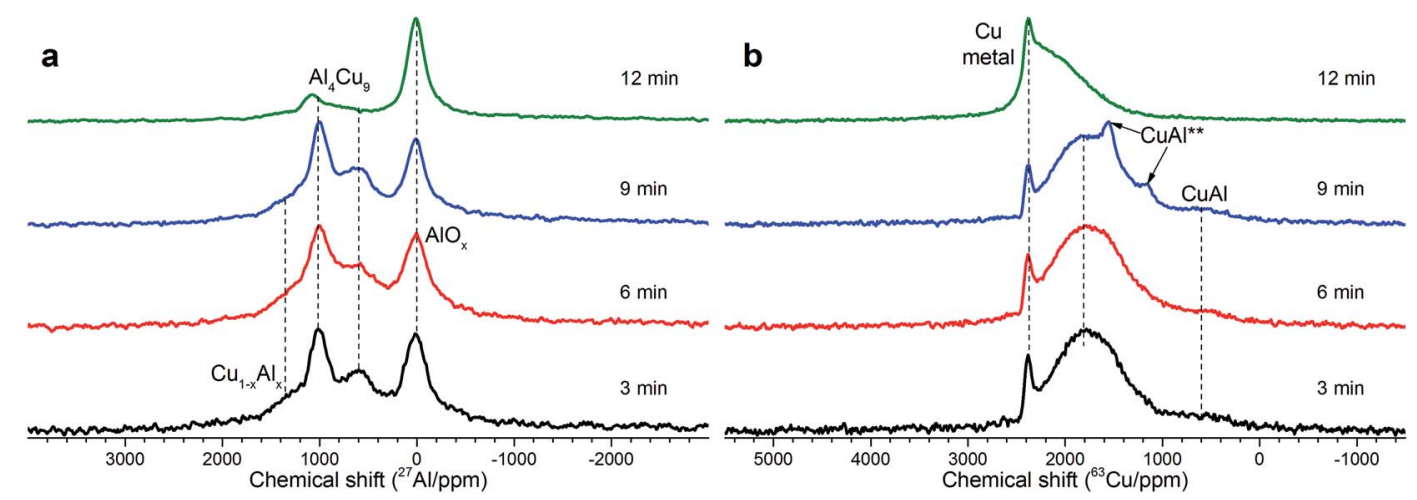

Fig. 2 (a) Static ${ }^{27} \mathrm{Al}$ NMR spectra of $\mathrm{Cu}-\mathrm{Al}$ cermets $(85: 13 \mathrm{wt} \%$ ) in dependence on the time of mechanical activation (down-top): $3,6,9$ and $12 \mathrm{~min}$. The intensity is normalized to maxima in the spectra. (b) Static ${ }^{63} \mathrm{Cu}$ NMR spectra of Cu-Al cermets (85: 13 wt\%) in dependence on MA time (down-top): 3, 6, 9 and 12 min. The intensity is normalized to maxima in the spectra.

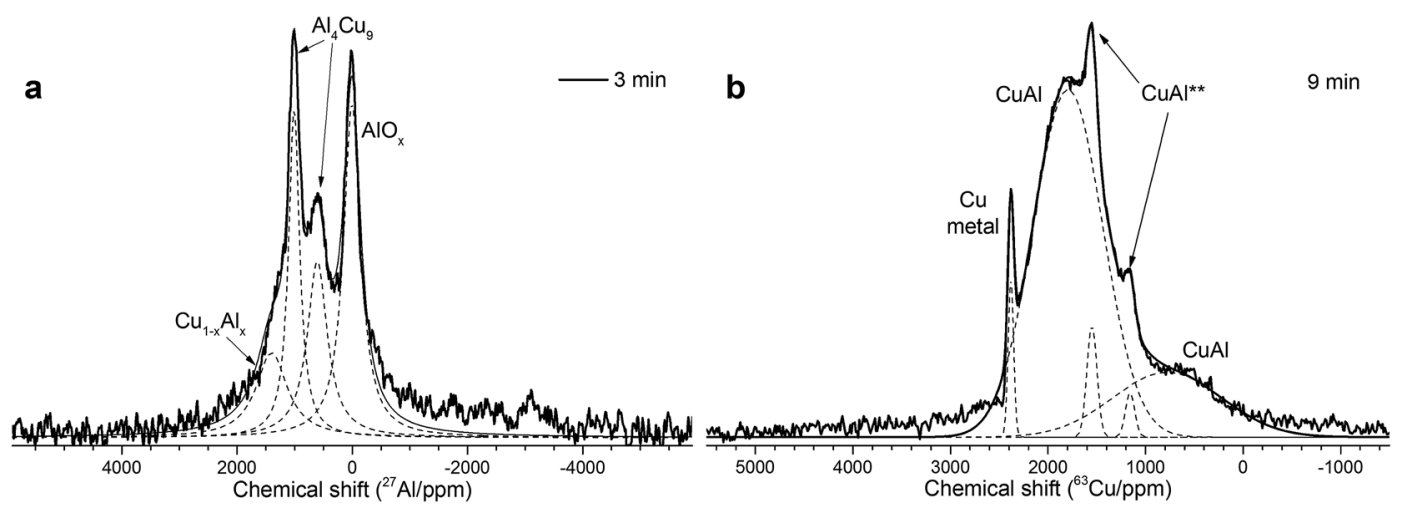

Fig. 3 (a) An example of ${ }^{27} \mathrm{Al}$ spectrum decomposition for the $\mathrm{Cu}-\mathrm{Al}$ cermet $\left(85: 13\right.$ wt\%) with 3 min activation time; (b) an example of ${ }^{63} \mathrm{Cu}$ spectrum decomposition for the $\mathrm{Cu}-\mathrm{Al}$ cermet $(85: 15 \mathrm{wt} \%)$ with 9 min activation time. 
to the skin effect, not all aluminum atoms are excited equivalently.

MAS spectra in Fig. 4 show a better resolution of the lines displayed in Fig. 2a. The shoulder at 1400 ppm disappears since its width is not averaged under MAS conditions. First, the Al oxide part is resolved to ensure the separation of octahedral ( $\sim 0 \mathrm{ppm})$ and tetrahedral $(\sim 60 \mathrm{ppm}) \mathrm{Al}$ sites. Another feature of $15 \mathrm{kHz}{ }^{27} \mathrm{Al}$ spin echo MAS spectra is the emergence of a rather narrow line near $\sim 900 \mathrm{ppm}$. Such a small width may correspond to a well-crystallized $\mathrm{Cu}-\mathrm{Al}^{* *}$ compound containing less than 1 at $\%$ of the observed Al. It can be concluded from the data shown in Fig. 4 that concentration of the $\mathrm{Cu}-\mathrm{Al}^{* *}$ compound increases with MA time up to 9 min and completely disappears after 12 min of activation.

The simulation of $\mathrm{Al}_{\mathrm{T}}$ and $\mathrm{Al}_{\mathrm{O}}$ sites of $15 \mathrm{kHz}$ echo MAS ${ }^{27} \mathrm{Al}$ NMR spectra by simple Czjeck model gives $\mathrm{Al}_{\mathrm{O}} / \mathrm{Al}_{\mathrm{T}}$ ratios from 1.1 to 0.6 . Neither of the ratios corresponds to a certain alumina that generally has $\mathrm{Al}_{\mathrm{O}} / \mathrm{Al}_{\mathrm{T}}$ in the range between 2 and $37 .{ }^{26,27}$ This observation coupled with a broad basement under main $\mathrm{AlO}_{x}$ peaks and abnormally intensive satellite lines suggests that samples composition could be close to $\mathrm{CuAl}_{2} \mathrm{O}_{4}$ which is a partially inversed spinel; moreover, samples may contain delafossite or $\mathrm{Cu}_{x} \mathrm{Al}_{y} \mathrm{O}_{z}$ structures. ${ }^{28,29}$

3.1.3. ${ }^{63} \mathrm{Cu}$ NMR. Static spin echo ${ }^{63} \mathrm{Cu}$ spectra are shown in Fig. 2b. It is important to mention that paramagnetic $\mathrm{CuO}$ does not contribute to ${ }^{63} \mathrm{Cu}$ NMR spectra, therefore, it is not considered here. Nevertheless, the spectra are highly informative and display different $\mathrm{Cu}$ environments. First of all, a distinct line of $\mathrm{Cu}$ metal is found at $\sim 2390 \mathrm{ppm}$. Despite hydrothermal treatment and calcination, $\mathrm{Cu}$ metal is still present in the sample. Since Cu metal phase was not detected by $\mathrm{XRD}$ in these samples (Fig. 1), this means that $\mathrm{Cu}$ particles size is less than 1-2 nm and/or their amount is small. The rest part of spectra corresponds to $\mathrm{Cu}-\mathrm{Al}$ intermetallic compounds. Unfortunately, several non-equivalent $\mathrm{Cu}$ sites of the compound are not resolved in ${ }^{63} \mathrm{Cu}$ NMR due to their large width ( $\sim 1790$ and $\sim 790 \mathrm{ppm}$ for all samples), therefore no certain line can be attributed to $\mathrm{Al}_{4} \mathrm{Cu}_{9}$ or $\mathrm{Cu}_{x} \mathrm{Al}_{1-x}$ etc., which is designated as "CuAl" (Fig. 2b). The broad character of these lines is also

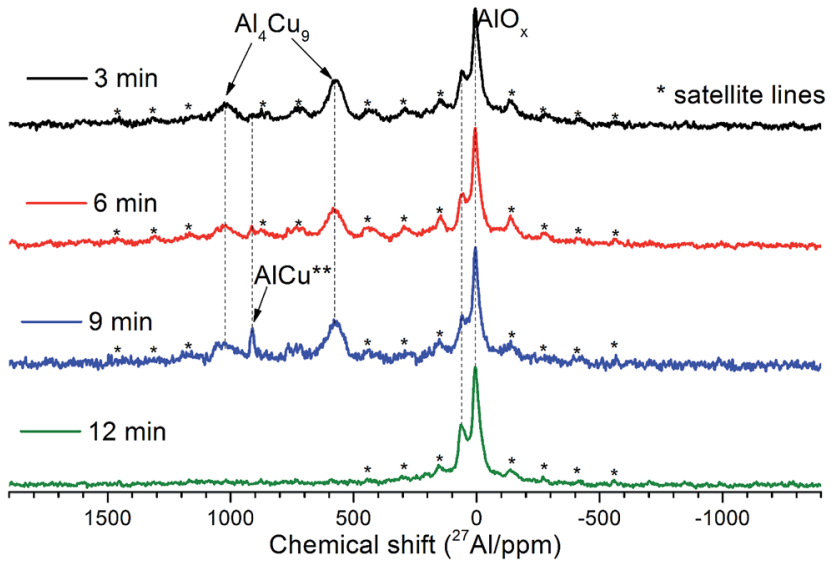

Fig. $415 \mathrm{kHz}$ spin echo ${ }^{27} \mathrm{Al}$ MAS spectra of $\mathrm{Cu}$-Al cermets for the sample activated for 3, 6, 9 and $12 \mathrm{~min}$. associated with the additive line shift caused by a gradual change of copper environment from pure $\mathrm{Cu}(\mathrm{Cu}$ metal) to $\mathrm{Cu}(x \mathrm{Al}, y \mathrm{Cu})$, which exhibits lower values of the chemical shift. Moreover, an obvious correlation can be drawn between narrow lines in the 9 min sample, which emerge in ${ }^{63} \mathrm{Cu}$ and ${ }^{27} \mathrm{Al}$ MAS NMR spectra (Fig. 2a and b). These lines are attributed to a well crystallized $\mathrm{AlCu}^{* *}$ compound having a certain stoichiometry with one non-equivalent $\mathrm{Al}$ site and two non-equivalent $\mathrm{Cu}$ sites. However, the amount of this compound is low and does not exceed $1 \mathrm{wt} \%$. This phase may be related to the phase observed in XRD (Fig. 1).

In general, according to XRD and NMR data, the content of $\mathrm{Cu}-\mathrm{Al}$ phases $\left(\mathrm{Al}_{4} \mathrm{Cu}_{9}, \mathrm{CuAl}^{* *}\right.$, etc. $)$ passes through the maximum with increasing the MA time, whereas $\mathrm{CuO}$ oxide shows an opposite behavior. Ceramometals prepared at all times of mechanical activation contain a noticeable amount of oxides, most likely in the form of mixed $\mathrm{Cu}-\mathrm{Al}$ oxides. However, these compounds are very dispersed and XRD amorphous.

\subsection{Microstructure and space distribution of oxide and metal phases in the bulk of $\mathrm{Cu}-\mathrm{Al}-\mathrm{O} / \mathrm{CuAl}$ cermets}

Fig. 5 displays the microstructure of cermets as revealed by SEM. As seen in this Figure and confirmed by EDX data (Fig. 6), all cermets consist of metallic cores surrounded with the oxide layer, thus forming a microshell structure. Macropores observed as dark patches in Fig. 5 are situated between stacked cermet particles. The oxide layer forms a framework that integrates all the components into a monolith. The composition of the metallic core is close to that of the initial blend. The averaged composition of the oxide layer, according to the mapping data presented as a diagram (Fig. 6), is close to $\mathrm{Cu}_{2} \mathrm{AlO}_{3-4}$. Such a composition has an excess of copper in comparison with copper-aluminum spinel. Oxide fragments with the stoichiometry $\mathrm{CuAlO}_{2+x}$ (corresponds to the structure of rhombohedral or hexagonal modifications of delafossite) ${ }^{30}$ and $\mathrm{CuO}$ were often observed in samples activated for 9 and $12 \mathrm{~min}$. The thickness of the oxide layer decreases with increasing the MA time. Sample activated for 9 min has oxide "streaks" which may result from cracking of brittle copper-aluminum alloys. Sample activated for 12 min has many fine particles which are completely oxidized upon calcination in air. Black spots correspond to epoxy resin penetrating through ultramacropores of cermets to a depth of $500 \mu \mathrm{m}$. Thus, the oxide part of ceramometals after calcination in air concentrates mostly at the external surface of cermet macropores, sometimes as "streaks" due to cracking of metallic cores.

The ratio of the oxide and metal parts of ceramometals can be qualitatively estimated from the phase diagrams obtained by the elemental mapping. As seen in Fig. 6, the intensity of the metallic part (Fig. 6a, a spot near the $\mathrm{Cu}-\mathrm{Al}$ line with the oxygen content close to zero) in the sample activated for $3 \mathrm{~min}$ is much higher as compared to the oxide one. The $12 \mathrm{~min}$ sample (Fig. 6d) shows an opposite pattern, in spite of a lower thickness of the oxide layer. The latter may be caused by the dispersion of the $\mathrm{Cu}-\mathrm{Al}$ precursor during its mechanochemical synthesis. ${ }^{13,24}$ This increases the total Me/air interfacial area, thus facilitating 

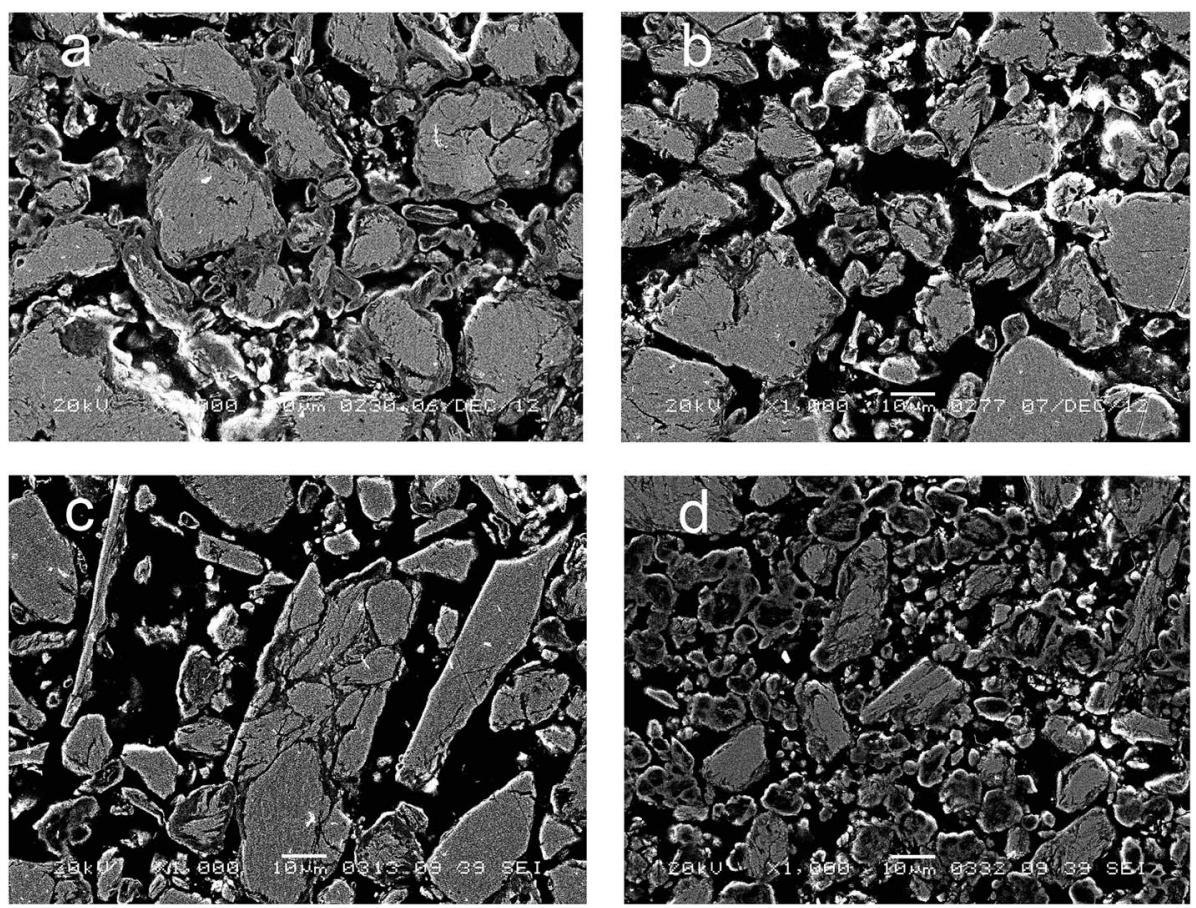

Fig. 5 Electron microscopy images of $\mathrm{Cu}-\mathrm{Al}-\mathrm{O}$ cermet sections obtained from MA products at different alloying time: (a) 3 min, (b) 6 min, (c) $9 \mathrm{~min}$, (d) $12 \mathrm{~min}$.
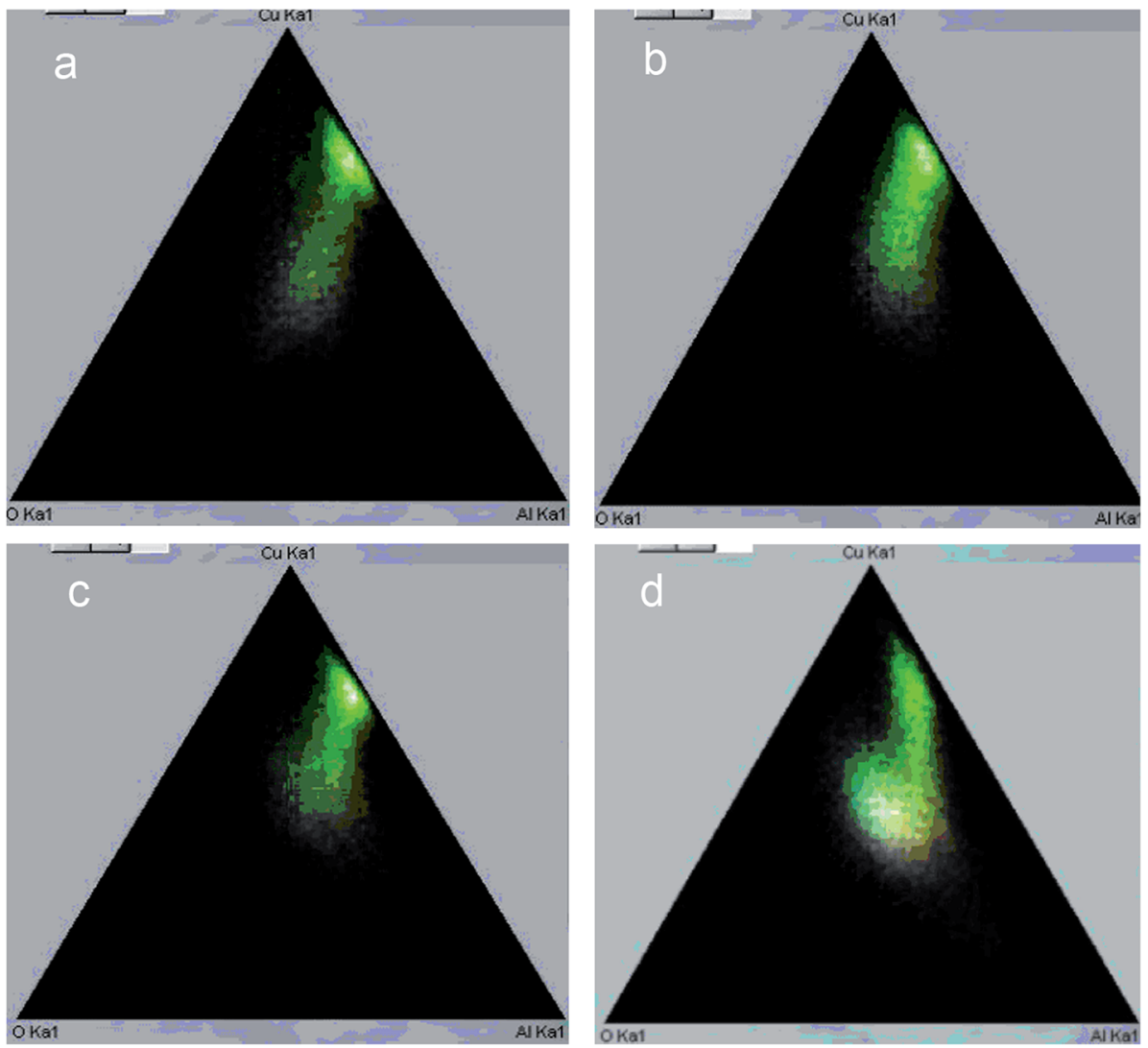

Fig. 6 Phase diagram according to EDX mapping of $\mathrm{Cu}-\mathrm{Al}-\mathrm{O}$ cermet sections obtained from MA products at different alloying time: (a) 3 min, (b) 6 min, (c) 9 min, (d) 12 min. 
an increase in the oxide amount even at a smaller thickness of the oxide layer.

The presence of aluminum oxide in the surface layer of ceramometals was additionally confirmed by XPS analysis. X-ray photoelectron spectroscopy was used to examine a series of catalysts treated in oxygen and hydrogen at $270{ }^{\circ} \mathrm{C}$. Their typical spectra are displayed in Fig. 7. One can see that the spectrum recorded after oxidative treatment has the $\mathrm{Al} 2 \mathrm{p}$ peak with the binding energy of $74.5 \mathrm{eV}$ (Fig. 7a). This position of the peak is typical for $\mathrm{Al}^{3+}$ ions in $\mathrm{Al}_{2} \mathrm{O}_{3}$ oxide $(74.2-74.6 \mathrm{eV}) \cdot{ }^{31-34}$ Additional peaks in the region of high binding energies correspond to the $\mathrm{Cu} 3 \mathrm{p}_{3 / 2}-\mathrm{Cu} 3 \mathrm{p}_{1 / 2}$ doublet. A shift of the $\mathrm{Cu} 3 \mathrm{p}_{3 / 2}-\mathrm{Cu} 3 \mathrm{p}_{1 / 2}$ doublet to lower binding energies and increase in their relative intensity indicate reduction of copper cations on the surface.

The analysis of $\mathrm{Cu} 2 \mathrm{p}$ spectra revealed that the chemical (and, probably, structural) state of the surface layers of ceramometals is very complicated (Fig. 7b). On the one hand, according to XPS data, the $\mathrm{Cu}: \mathrm{Al}$ atomic ratio is $\sim 1: 1.4 / 1.5$ (3 and 12 min of MA) and $1: 1.0 / 1.1$ ( 9 and 6 min of MA). It means that the cationic stoichiometry in the surface layers is closer to that of $\mathrm{CuAlO}_{2}$ delafossite ${ }^{30}$ or other structures of a mixed oxide in which the oxidation state of copper is $1+$. On the other hand, copper in the surface layers of the oxidized catalyst is mostly in the $\mathrm{Cu}^{2+}$ state. This statement is evidenced by the binding energy of $\mathrm{Cu} 2 \mathrm{p}_{3 / 2}$ equal to $935.9 \mathrm{eV}$, the intensity ratio of the main peak to shake-up satellite (0.46), and the Auger parameter equal to $1851.4 \mathrm{eV}^{33-35} \mathrm{CuO}$ oxide is usually characterized by a lower binding energy of $\mathrm{Cu} 2 \mathrm{p}_{3 / 2}$, in the range of 933.6$934.6 \mathrm{eV}^{34,36-43}$ This phenomenon can be attributed to the presence of subnanosized $\mathrm{Cu}-\mathrm{O}$ clusters in the surface layers of ceramometals. In such clusters, the initial oxide state is close to $\mathrm{Cu}^{2+}$; however, they can easily loose oxygen even in a weakly reducing medium up to the $\mathrm{Cu}^{0}$ state which is active in the WGSR. ${ }^{34}$ Indeed, after treatment in hydrogen, the peaks of shake-up satellites typical of $\mathrm{Cu}^{2+}$ disappear from the $\mathrm{Cu} 2 \mathrm{p}$ spectrum, and the Auger parameter becomes equal to 1851.3, which indicates a complete reduction of copper to the metallic state.

Hence, CuAlO/CuAl ceramometal catalysts have a complex arrangement. Their metallic cores are comprised of the solid solution of aluminum in copper and the intermetallic, which prevent a complete oxidation of the metal component upon calcination in air. The oxide component, which has a thickness of several microns, is X-ray amorphous and forms a joint framework. This component includes at least the mixed oxides of copper and aluminum and, possibly, copper-oxygen clusters. As the time of preliminary MA of the $\mathrm{Cu}-\mathrm{Al}$ precursor is increased, concentration of the solid solution goes through the maximum, and that of $\mathrm{CuO}$ - through the minimum for sample $6 \mathrm{~min}$ of $\mathrm{MA}$, while concentration of intermetallics $\left(\mathrm{Al}_{4} \mathrm{Cu}_{9}\right.$ and unknown phase) goes through the maximum for sample with 9 min of MA (Table 1, Fig. 7). An increase in the concentration of the oxide component with time of MA is related also to deagglomeration of the brittle $\mathrm{Cu}(\mathrm{Al})$ solid solution, which forms already at the MA step ${ }^{13}$ thus increasing the metal/gas interfacial area.

\subsection{Specific activity in WGSR and the nature of active surface sites}

Temperature dependences of $\mathrm{CO}$ conversion for ceramometal catalysts are given in Fig. 8 in comparison with known commercial analog of ceramic catalyst (CZA). ${ }^{10}$ At close space velocities (4200-4400 $\mathrm{h}^{-1}$ for CuAl ceramometals and $\sim 5000 \mathrm{~h}^{-1}$ for CZA catalyst) CO conversions are apparently higher for CZA catalyst. Conversions clearly increase with the time of $\mathrm{MA}$ of $\mathrm{Cu}-\mathrm{Al}$ mixture, even exceeding those for $\mathrm{CZA}$ catalyst in the case of sample activated for $12 \mathrm{~min}$.

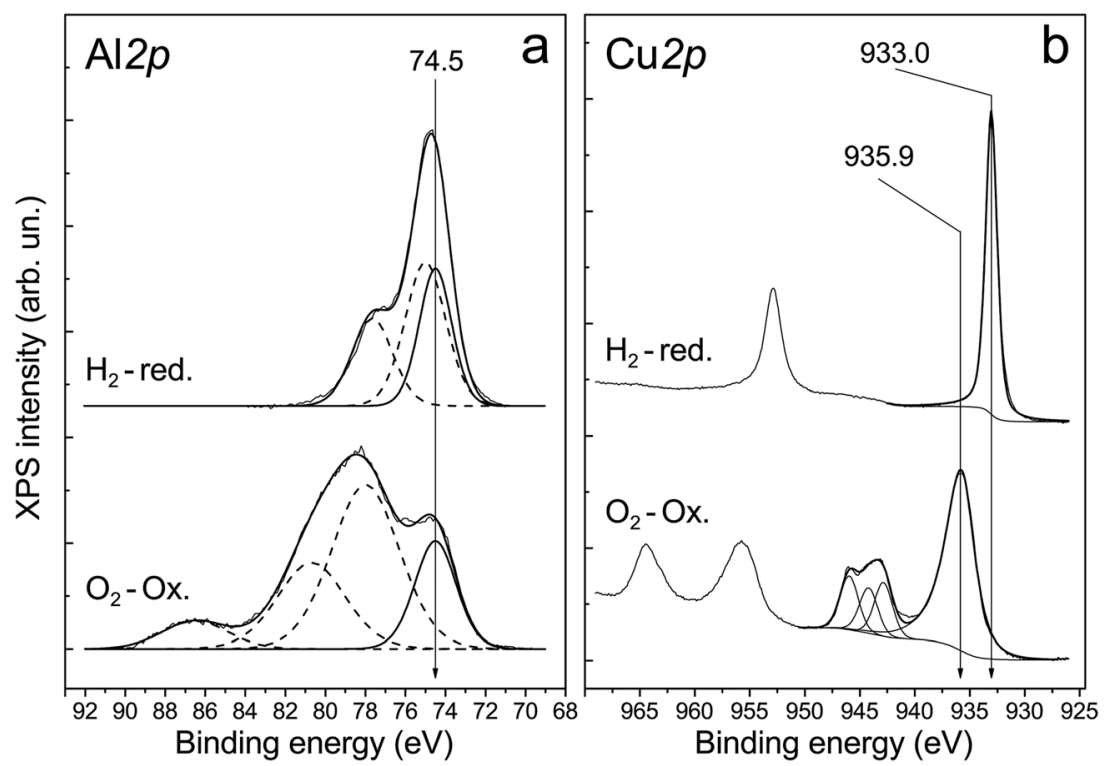

Fig. 7 Core-level XPS spectra obtained after treatment of the catalyst in 1 bar $\mathrm{O}_{2}$ at $270{ }^{\circ} \mathrm{C}\left(\mathrm{O}_{2}-\mathrm{O}_{x}\right)$ and in 1 bar $\mathrm{H}_{2}$ at $270{ }^{\circ} \mathrm{C}\left(\mathrm{H}_{2}\right.$-red) directly in the high pressure cell of the photoelectron spectrometer. 


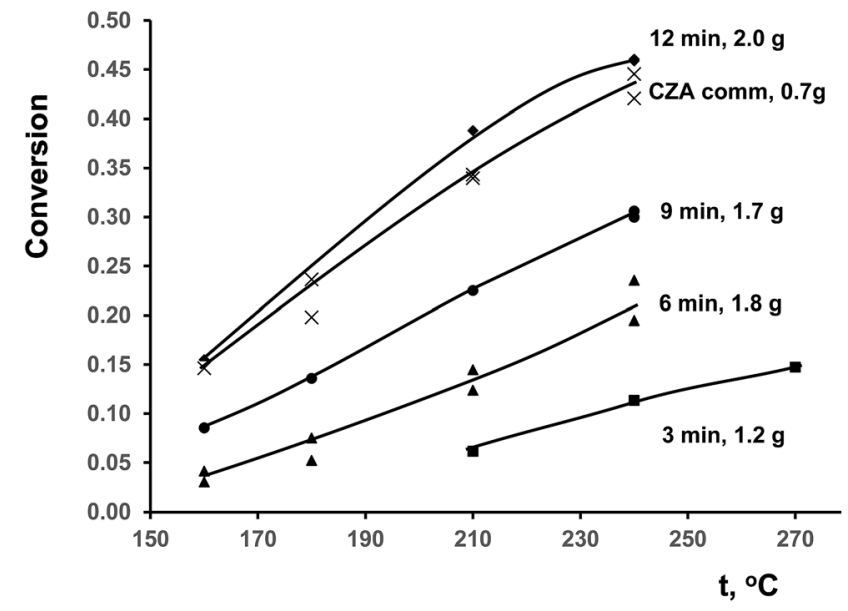

Fig. 8 Temperature dependence of CO conversion in WGSR for studied catalysts. The weights of samples were varied due to difference of loading density.

Due to different specific densities of ceramometals a proper comparison of their catalytic activity requires estimation of specific rate constants listed in Table 2 . When the rate constant is estimated using the equation for the plug-flow reactor, an important parameter is the contact time, which at the same weight hourly space velocity depends on the volume of the catalyst bed. In the case of ceramometal catalysts, their much higher density due to presence of metallic particles should be taken into account. This results in a substantial decrease in the volume of the catalytic layer at comparable catalyst weights (Table 2). The estimated rate constant $\left(k, \mathrm{~s}^{-1}\right)$ at $240{ }^{\circ} \mathrm{C}$ monotonically increases with the time of preliminary MA approximately by a factor of 2.5 , but remains lower as compared to that for the porous oxide catalyst (Table 2). Stability of the catalysts changes in a similar way, while stability of CZA is better. Obviously, the key factor determining the catalyst activity is the specific surface area; on the average, its value for the ceramic analog exceeds that for ceramometal catalysts by an order of magnitude (Table 2).

However, the specific (per the unit surface area) activity of ceramometal catalysts is $2-3$ times higher as compared to ceramic copper-zinc-aluminum one (see Table 2 : $k /(m \times S)$ ). It means that the concentration of active sites (known to be copper atoms $)^{1,2}$ on the surface of ceramometal catalysts is substantially higher.
In principle, this observation is supported by XPS data, according to which the concentration of copper on the surface of all ceramometal catalysts after catalytic testing is higher in comparison with ceramic CZA one (Table 2). It should be noted that reduction of these catalysts decreases the surface copper concentration, but the general tendency is preserved. In a similar way, the surface concentration of copper in various oxides with the perovskite structure was found to be approximately twofold higher as compared to copper catalysts for WGSR. $^{44}$

A more detailed analysis showed that changes in the copper concentration on the surface $(\sim 30 \%)$ are not so pronounced as changes in specific activity ( $200 \%$ ) (Table 2$)$. Thus, it can be assumed that differences between the catalysts are caused not only by the concentration of active sites but also by a considerable difference in specific activity of these sites. This is confirmed also by the values of constants referred to the unit surface area of metallic copper, which were estimated form XPS data and the total specific surface area of the catalysts. For most of ceramometal catalysts, the indicated values are higher than for the oxide catalyst (Table 2). Thus, ceramometal catalysts have sites with a higher specific activity as compared to the conventional catalyst containing mixed oxides. The concentration of such sites on the surface of ceramometals goes through the maximum as the time of preliminary MA is increased (Table 2). An essential difference in the activity per the unit surface area of metallic copper was observed in earlier works as well. ${ }^{1,44,45}$

As shown by XRD, samples of ceramometal catalysts after catalytic testing have nearly the same phase composition as the initial samples, except for $\mathrm{CuO}$, which turns into metallic copper (Fig. 9). With the increase of the time of preliminary mechanical alloying of $\mathrm{Cu}-\mathrm{Al}$ powder the average crystallite size of the solid solution decreases from $25-34 \mathrm{~nm}$ to $\sim 11 \mathrm{~nm}$, and that of the $\mathrm{Al}_{4} \mathrm{Cu}_{9}$ intermetallic - from 33-46 to $14-19 \mathrm{~nm}$. The size of metallic copper particles changes non-monotonically. First it decreases from $17-24$ ( 3 min MA) to 7-10 nm for the $6 \mathrm{~min}$ sample, and then increases to $28-40 \mathrm{~nm}$ for the $12 \mathrm{~min}$ sample. However, we should stress that XRD is not able to distinguish particles of metallic copper formed on the surface of oxide microshell envelope and its crystallites located within the metal core of ceramometals. Moreover, XRD is not able to detect nanoparticles with the size below $2 \mathrm{~nm}$. Thus, according to NMR data, in the initial ceramometals metallic copper is

Table 2 Catalytic properties of CuAl cermets $\left(240^{\circ} \mathrm{C}\right)(0.14-0.25 \mathrm{~mm} \text { fraction })^{a}$

\begin{tabular}{|c|c|c|c|c|c|c|c|c|c|}
\hline Sample & $m, \mathrm{~g}$ & $\delta_{\text {gran }}, \mathrm{g} \mathrm{cm}^{-3}$ & $\delta_{\text {cat.bed }}, \mathrm{g} \mathrm{cm}^{-3}$ & $k, \mathrm{~s}^{-1}$ & $\begin{array}{l}\text { Stability, } \\
\text { arb.un. }\end{array}$ & $S_{\mathrm{BET}}, \mathrm{m}^{2} \mathrm{~g}^{-1}$ & $k /\left(m \times S_{\mathrm{BET}}\right), \mathrm{s}^{-1} \mathrm{~m}^{-2}$ & $\mathrm{Cu} /(\mathrm{Cu}+\mathrm{Al})$ & $k /\left(m \times S_{\mathrm{Cu}}\right), \mathrm{s}^{-1} \mathrm{~m}^{-2} \mathrm{Cu}$ \\
\hline $\operatorname{CuAl}(3)$ & 1.24 & 4.24 & $\sim 2.3$ & 2.8 & 0.6 & 14.4 & 0.2 & 0.59 & $\sim 0.3$ \\
\hline $\operatorname{CuAl}(9)$ & 1.71 & 4.00 & $\sim 2.1$ & 4.8 & 0.8 & 9.0 & 0.3 & 0.52 & $\sim 0.6$ \\
\hline $\operatorname{CuAl}(12)$ & 2.00 & 3.87 & $\sim 2.0$ & 7.8 & 0.9 & 15.7 & 0.2 & 0.59 & $\sim 0.3$ \\
\hline CZA comm & 0.70 & 2.00 & $\sim 1.0$ & 9.1 & $>0.9$ & 121 & 0.1 & 0.39 & $\sim 0.3$ \\
\hline
\end{tabular}

${ }^{a} \delta_{\text {cat.bed }}$ - catalyst bed density; $\mathrm{Cu} /(\mathrm{Cu}+\mathrm{Al})$ - from XPS data. 


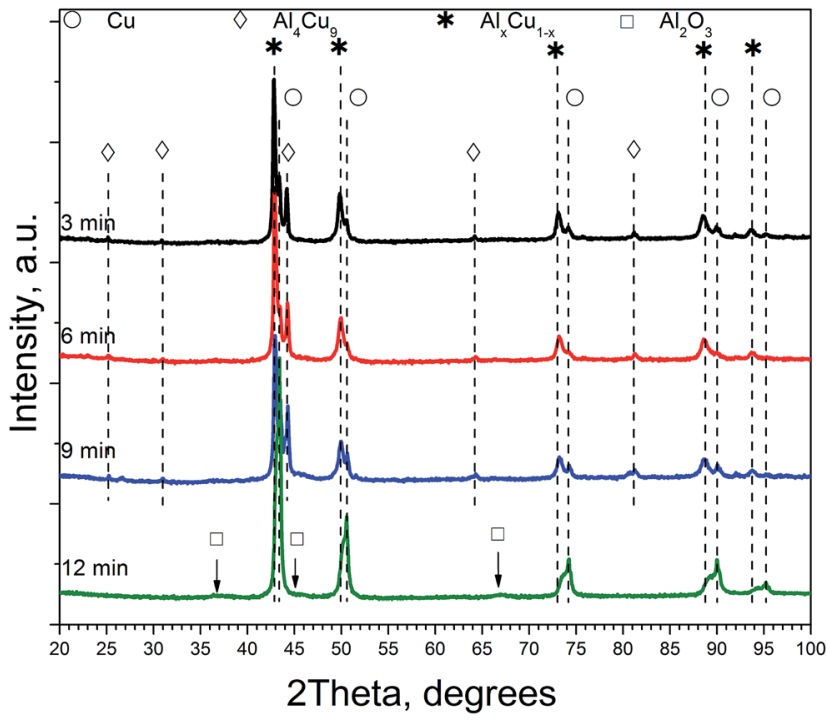

Fig. 9 Diffraction patterns of cermets at different MA times after reduction in hydrogen $\left(270{ }^{\circ} \mathrm{C}\right)$ and catalytic experiments. Symbols denote peaks corresponding to the following phases: * - solid solution of aluminum in copper, $\mathrm{Al}_{x} \mathrm{Cu}_{1}, \diamond-\mathrm{Al}_{4} \mathrm{Cu}_{9}$ intermetallic [24-0003], $\mathrm{O}-\mathrm{Cu}$ [04-0836], $\square-\mathrm{Al}_{2} \mathrm{O}_{3}$.

present, while it is not revealed by XRD (vide supra Fig. 1-3). Hence, analysis of X-ray particle sizes for metallic copper in $\mathrm{CuAlO} / \mathrm{CuAl}$ ceramometals is apparently not informative as compared with XPS data.

A comparison of the values of constants referred to the unit surface area of metallic copper by XPS data with the content of the $\mathrm{Al}_{4} \mathrm{Cu}_{9}$ intermetallic in cermets revealed quite a good correlation of these values (Fig. 10). Note that the unknown intermetallic phase also has a maximum concentration in the sample activated for 9 min (Fig. 4) with the highest activity per the surface site. This suggests that the highly active sites of metallic copper are located on the surface of various copper and aluminum alloys, or more exactly, on the surface of the oxide substrate that forms a microshell envelope on the surface of these cores after HTT and calcination in air. The activity of such sites is much higher as compared to the known sites, so their structure should have some distinctive features. Most likely, these sites are associated with copper in a high dispersion having a clustered subnanosized structure. According to the literature, the specific surface area of metallic copper particles tested in WGSR does not exceed $35 \mathrm{~m}^{2} \mathrm{~g}^{-2}$; so in a spherical approximation, this gives the particle size not smaller than $19 \mathrm{~nm}$. In our case, copper clusters on the surface of ceramometals seem to have a much smaller size, which could make them much more active.

In an earlier study on steam reforming of methanol over the catalysts synthesized from $\mathrm{Cu}-\mathrm{Al}-\mathrm{Fe}$ alloys, a conclusion was made on the presence of "dispersed copper particles which cannot be observed by XRD". ${ }^{11}$ Later, the presence of dispersed particles was associated with the formation of a thin oxide layer on the surface of $\mathrm{Cu}-\mathrm{Al}-\mathrm{Fe}$ alloy, which stabilizes the dispersed copper particles. ${ }^{12}$ The effect of a substrate on the properties of such subnanoparticles (clusters) is caused not only by

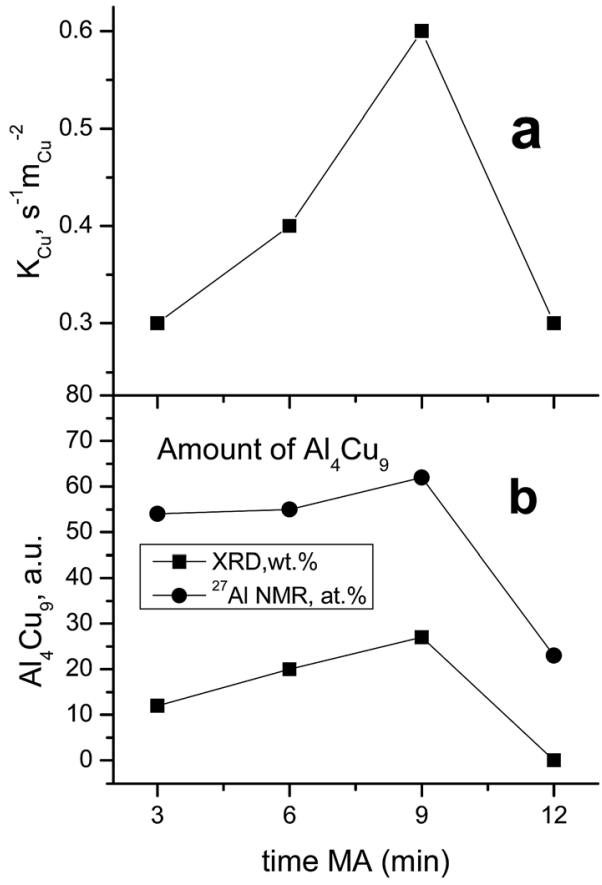

Fig. 10 The effect of the time of preliminary MA of the Cu-Al precursor on specific catalytic activity of surface copper (a) and a relative content of $\mathrm{Al}_{4} \mathrm{Cu}_{9}$ intermetallic according to XRD and NMR data (the content of aluminum in cermets with respect to that in other phases) (b).

stabilization of subnanosizes but also by a partial distortion of the structure and variation of the chemical properties due to a strong interaction with support. ${ }^{35}$ The surface structure of the $\mathrm{Al}_{4} \mathrm{Cu}_{9}$ intermetallic, which was described in detail in, ${ }^{46}$ can be used as an example to analyze the effect of such alloys on the formation of subnanodispersed structures of metallic copper on their surface. Thus, for the (110) face, aluminum actually 'decorates' the surface of metallic copper, separating it into the aggregates including from two to some tens of copper atoms. It is well known that the bulk oxidation of aluminum alloys with transition metals is hindered by the formation of a dense oxide layer. The formation of the subsurface layer during HTT and calcination in air may be accompanied by the emergence of oxide subnanostructures differing from the structures of bulk oxides observed by structural methods. In the course of reductive treatments, copper will change its oxidized state to the metallic one, whereas aluminum will not do this. Overall, this should stabilize copper subnanoparticles (clusters), which possess an increased catalytic activity. Similar stable nanocomposites $\mathrm{Cu} / \mathrm{Al}_{2} \mathrm{O}_{3}$, which are formed upon reduction of copper and aluminum mixed oxides with the delafossite structure by hydrogen are reported in the literature..$^{30}$

More coarse particles of metallic copper observed by XRD in oxidized cermets are formed most likely from copper oxide. ${ }^{12}$ The absence of a strict correlation between concentration of intermetallic or copper on the surface and specific activity may be caused by changes in the ratio of nanodispersed and more active subnanodispersed copper stabilized on the surface of intermetallic in dependence on the properties of the precursor. 
Table 3 Textural and mechanic properties CuAl cermets and CZA catalyst

\begin{tabular}{llcllr}
\hline Sample & Time MA, min & SSA, $\mathrm{m}^{2} \mathrm{~g}^{-1}$ & $V_{\text {meso }}, \mathrm{cm}^{3} \mathrm{~g}^{-1}$ & $V_{\text {macro }} \mathrm{cm}^{3} \mathrm{~g}^{-1}$ & Compress. strength, MPa \\
\hline CuAl(3) & 3 & 14.4 & 0.02 & 0.05 & 10.5 \\
CuAl(6) & 6 & 9.9 & 0.01 & 0.06 & 9.9 \\
CuAl(9) & 9 & 9.0 & 0.02 & 0.07 & 7.7 \\
CuAl(12) & 12 & 15.7 & 0.04 & 0.04 & 9.7 \\
CZA & - & 122 & 0.25 & $<0.001$ & 8.0
\end{tabular}

\subsection{Pore structure and its effect on the strength and activity}

The volume of micro- and mesopores in ceramometal catalysts is not high (0.01-0.04 $\mathrm{cm}^{3} \mathrm{~g}^{-1}$ ) (Table 3). It is much lower as compared to the bulk oxide analog $\left(0.25 \mathrm{~cm}^{3} \mathrm{~g}^{-1}\right)$. This determines a much higher specific surface of the latter (Table 3 ). However, the macropore volume $(>0.1 \mu \mathrm{m})$ of ceramic catalyst estimated from the difference between the total pore volume and mesopore volume is close to zero, whereas for ceramometal catalysts it is equal to $0.04-0.07 \mathrm{~cm}^{3} \mathrm{~g}^{-1}$ (Table 3). Macropores of ceramometals with the size up to tens of microns are clearly seen as black spots on the electron microscopy images (Fig. 6). These macropores are located between cermet particles comprised of the metal cores with the oxide shell, while mesopores are situated in the oxide shells. The macropore volume changes non-monotonically and contrariwise to the strength of cermets. Sample with 9 min of MA has a minimum strength (Table 3). However, irrespective of the developed macropore structure, which usually results in the decrease of the catalyst strength, the total strength of ceramometals is comparable with the strength of ceramic catalyst $(8 \mathrm{MPa})$.

The developed macropore structure should enhance the diffusion permeability of the granules which is a traditional shape of industrial catalysis. ${ }^{44}$ A high diffusion permeability will equalize the activity of the coarse fraction of ceramometal catalysts and ceramic catalyst. Indeed, the activity of a small fraction of cermet (12 min MA) was lower as compared to that of the oxide catalyst, whereas an opposite trend was observed for the coarse fraction (Fig. 11): activity of the $3 \times 5 \mathrm{~mm}^{2}$ cermet granules $\left(k=5.1 \mathrm{~s}^{-1}\right)$ exceeded by more than $20 \%$ the activity of granulated oxide catalyst $\left(k=4.4 \mathrm{~s}^{-1}\right)$. Thus, when going from a fine to a coarse fraction, activity of the cermet decreases by $35 \%$, and activity of the oxide catalyst by $52 \%$. Note also that the density of ceramometals $\left(\sim 4 \mathrm{~g} \mathrm{~cm}^{-3}\right)$ is substantially higher than that of CZA $\left(\sim 2 \mathrm{~g} \mathrm{~cm}^{-3}\right)$, while for known oxide catalysts the density is even lower $\left(\sim 1 \mathrm{~g} \mathrm{~cm}^{-3}\right),{ }^{10}$ which compensate their

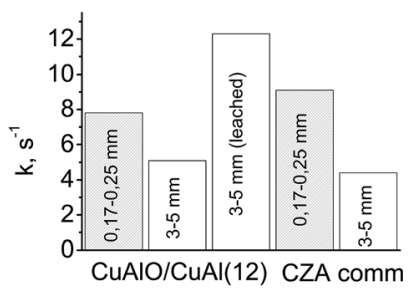

Fig. 11 Activity of small and coarse fractions of different catalysts in WGSR $\left(240{ }^{\circ} \mathrm{C}, \mathrm{CO}: \mathrm{H}_{2} \mathrm{O}: \mathrm{H}_{2}=8: 42: 50\right)$. high activity per the mass unit. These factors are important arguments demonstrating that ceramometal catalysts are promising for WGSR.

Leaching that promotes formation of additional nanostructures based on copper oxide can be an additional factor increasing the concentration of surface active sites. ${ }^{47}$ In steam reforming of methanol over the catalysts synthesized from $\mathrm{Cu}-$ $\mathrm{Al}-\mathrm{Fe}$ alloys, a mild leaching results in the substantial increase of activity. ${ }^{\mathbf{1 1 , 1 2}}$ In our study, a similar treatment of cermet granules also gave more than a twofold increase in the catalyst activity (Fig. 11).

This effect can be also related to the presence of aluminumenriched layers on the surface of $\mathrm{Cu}-\mathrm{Al}$ alloys. ${ }^{46}$ After oxidative treatments, such a layer will be oxidized and block the surface of metallic copper. Upon leaching of aluminum, blocking of the surface will decrease and activity will increase. It cannot be ruled out that the decreased activity for 3 and 6 min samples, irrespective of a relatively high concentration of the intermetallic (Fig. 10), is related exactly to the high concentration of aluminum in the surface layer, which decreases with increasing the MA time to 9 and $12 \mathrm{~min}$.

For the most active ceramometal $\mathrm{CuAlO} / \mathrm{CuAl}$ (MA time $12 \mathrm{~min}$ ), the effective linear thermal expansion coefficient for the temperature range of $25-500{ }^{\circ} \mathrm{C}$ was equal to $\sim 10 \times 10^{-6}$ $\left(\mathrm{deg}^{-1}\right)$. For other cermets, it varied within a range from 9 to $28 \times 10^{-6}\left(\mathrm{deg}^{-1}\right)$ in dependence on the MA time for a powdered precursor, affecting both the metal/oxide ratio and the pore volume of ceramometals. Overall, the variation range of thermal expansion coefficient makes it possible to select such conditions of the synthesis which would protect ceramometal coatings against cracking and peeling from the metal tubes or other metallic substrates (microchannel plates, foils, etc.). Thus, ceramometal catalysts are promising for use in compact devices for the production of hydrogen.

\section{Conclusions}

The evolution of the structure and microstructure of $\mathrm{CuAlO} /$ $\mathrm{CuAl}$ ceramometals synthesized by mechanochemical activation of the $\mathrm{Cu}+\mathrm{Al}$ mixture $(\mathrm{Cu}: \mathrm{Al}=87: 13 \mathrm{wt} \%)$ with subsequent hydrothermal treatment leading to integration of the powder into a monolith, drying and calcination was studied in dependence on the MA time. It was shown that such ceramometals have the egg-shell microstructure where the metallic cores containing aluminum and copper alloys are surrounded by the oxide matrix containing copper oxides and X-ray 
amorphous mixed oxides of copper and aluminum. The study revealed non-monotonic changes in the concentration of $\mathrm{Al}_{4} \mathrm{Cu}_{9}$ intermetallic in cermets to occur with variation of the MA time from 3 to $12 \mathrm{~min}$ and a similar change in the activity referred to the unit surface area. A high concentration as well as a high specific activity of metallic copper species located in the oxide shell covering intermetallic nuclei appear to be due to their subnanodispersed character.

The activity and textural-mechanical properties of cermets were compared with those for the conventional oxide catalyst containing mixed oxides of copper, zinc and aluminum. The activity of a fine $(0.14-0.25 \mathrm{~mm})$ fraction of ceramic catalyst was shown to exceed that of ceramometal catalysts due to the developed microporous structure, which provides nearly an order of magnitude greater specific surface area as compared to ceramometals. However, the macropore structure of such a catalyst is developed insufficiently. As a result, the activity of a coarse $(3-5 \mathrm{~mm})$ fraction of the ceramometal catalyst decreases to a smaller extent as compared to ceramic one, so their activities become comparable. In the average ceramometal granules possess twice as higher specific density as compared with that of ceramic catalysts. Mild leaching produces an additional increase in the activity of granulated cermets.

Large amount of metal particles provides a high thermal conductivity of ceramometals and makes it possible to construct a reactor with a controllable temperature profile along the catalyst bed, which is very important for providing a maximum efficiency of the process, not only of WGSR but any process running with a great thermal effect and having restrictions on the equilibrium or selectivity.

\section{Conflicts of interest}

There are no conflict to declare.

\section{Acknowledgements}

This work was in part supported by FP7 Project BIOGO.

\section{References}

1 G. C. Chinchen and M. S. Spencer, Catal. Today, 1991, 10, 293-301.

2 P. Kowalik, M. Konkol, K. Antoniak, W. Próchniak and P. Wiercioch, J. Mol. Catal. A: Chem., 2014, 392, 127-133.

3 T. Utaka, K. Sekizawa and K. Eguchi, Appl. Catal., A, 2000, 194-195, 21-26.

4 X. Lin, Y. Zhang, L. Yin, C. Chen, Y. Zhan and D. Li, Int. J. Hydrogen Energy, 2014, 39, 6424-6432.

5 A. Jha, D.-W. Jeong, W.-J. Jang, Y.-L. Lee and H.-S. Roh, Int. J. Hydrogen Energy, 2015, 40, 9209-9216.

6 A. Budiman, M. Ridwan, S. M. Kim, J.-W. Choi, C. W. Yoon, J.-M. Ha, D. J. Suh and Y.-W. Suh, Appl. Catal., A, 2013, 462463, 220-226.

7 R. T. Figueiredo, H. M. C. Andrade and J. L. G. Fierro, J. Mol. Catal. A: Chem., 2010, 318, 15-20.
8 C. Ratnasamy and J. P. Wagner, Catal. Rev.: Sci. Eng., 2009, 51, 325-440.

9 N. A. Baronskaya, T. P. Minyukova, A. A. Khassin, T. M. Yurieva and V. N. Parmon, Russ. Chem. Rev., 2010, 79, 1027-1046.

10 D. J. Moon and J. W. Ryu, Catal. Lett., 2004, 92, 17-24.

11 T. Tanabe, S. Kameoka and A. P. Tsai, Catal. Today, 2006, 111, 153-157.

12 T. Tanabe, S. Kameoka and A. P. Tsai, J. Mater. Sci., 2011, 46, 2242-2250.

13 D. V. Dudina, O. I. Lomovsky, K. R. Valeev, S. F. Tikhov, N. N. Boldyreva, A. N. Salanov, S. V. Cherepanova, V. I. Zaikovskii, A. S. Andreev, O. B. Lapina and V. A. Sadykov, J. Alloys Compd., 2015, 629, 343-350.

14 T. M. Yurieva, T. P. Minyukova, L. P. Davidova, O. V. Makarova, L. M. Plyasova and V. F. Anufrienko, Russian patent \#2046656, 1995.

15 B. Li and K. Xiao, J. Appl. Phys., 1992, 71, 3917-3921.

16 G. S. Carter, L. H. Bennett and D. J. Kahan, in Metallic Shifts in NMR, A review of theory and comprehensive critical data compilation of metallic materials (Progress in materials science, v. 20), ed. B. Chalmers, J. W. Christian and T. B. Massalski, Pergamon Press, Oxford, New York, Toronto, Sidney, Paris, Frankfurt, 1977, vol. 20, pp. 3-21.

17 L. Bai-qin and N. Chu, Acta Phys. Sin., 2000, 49, 155-159.

18 J. H. Scofield, J. Electron Spectrosc. Relat. Phenom., 1976, 8, 129-137.

19 D. A. Shirley, Phys. Rev. B: Solid State, 1972, 5, 4709-4714.

20 N. Fairley, www.casaxps.com.

21 Z. R. Ismagilov, R. A. Shkrabina and N. A. Koryabkina, Catal. Today, 1999, 47, 51-71.

22 B. S. M. Seeber, U. T. Gonzenbach and L. J. Gauckler, J. Mater. Res., 2013, 28, 2281-2287.

23 O. A. Kungurova, A. A. Khassin, S. V. Cherepanova, A. A. Saraev, V. V. Kaichev, N. V. Shtertser, G. K. Chermashentseva, E. Yu. Gerasimov, E. A. Paukshtis, O. V. Vodyankina, T. P. Minyukova and G. Abou-Jaoudé, Appl. Catal., A, 2017, 539, 48-58.

24 K. Wieczorek-Ciurowa, K. Gamrat and Z. Sawłowicz, J. Therm. Anal. Calorim., 2005, 80, 619-623.

25 R. Besson, M.-N. Avettand-Fènoël, L. Thuinet, J. Kwon, A. Addad, P. Roussel and A. Legris, Acta Mater., 2015, 87, 216-224.

26 K. J. D. MacKenzie and M. E. Smith, Multinuclear Solid State NMR of Inorganic Materials, Pergamon/Elsevier, Oxford, 2002, vol. 6 .

27 S. F. Tikhov, Y. V. Potapova, V. A. Sadykov, V. B. Fenelonov, I. V. Yudaev, O. Lapina, A. N. Salanov, V. I. Zaikovkii and G. S. Litvak, Mater. Res. Innovations, 2005, 9, 431-446.

28 E. Ghanti and R. Nagarajan, Dalton Trans., 2010, 39, 6056.

29 H. S. C. O'Neill, M. James, W. A. Dollase and S. A. T. Redfern, Eur. J. Mineral., 2005, 17, 581-586.

30 M. Kracum, A. Kundu, M. P. Harmer and H. M. Chan, J. Mater. Sci., 2015, 50, 1818-1824.

31 J. van den Brand, P. C. Snijders, W. G. Sloof, H. Terryn and J. H. W. de Wit, J. Phys. Chem. B, 2004, 108, 6017-6024. 
32 N. Kosova, E. Devyatkina, A. Slobodyuk and V. Kaichev, Solid State Ionics, 2008, 179, 1745-1749.

33 J. Mendialdua, R. Casanova, F. Rueda, A. Rodriguez, J. Quinones, L. Alarcon, E. Escalante, P. Hoffmann, I. Taebi and L. Jalowiecki, J. Mol. Catal. A: Chem., 2005, 228, 151-162.

34 B. R. Strohmeier, D. E. Levden, R. S. Field and D. M. Hercules, J. Catal., 1985, 94, 514-530.

35 S. F. Tikhov, V. A. Sadykov, G. N. Kryukova, E. A. Paukshtis, V. V. Popovskii, T. G. Starostina, G. V. Kharlamov, V. F. Anufrienko, V. F. Poluboyarov and V. A. Razdobarov, J. Catal., 1992, 134, 506-524.

36 L. Fu and H. Yang, J. Phys. Chem. C, 2014, 118, 14299-14315. 37 J. Batista, A. Pintar, D. Mandrino, M. Jenko and V. Martin, Appl. Catal., A, 2001, 206, 113-124.

38 V. I. Bukhtiyarov, V. V. Kaichev and I. P. Prosvirin, Top. Catal., 2005, 32, 3-15.

39 N. S. McIntyre and M. G. Cook, Anal. Chem., 1975, 47, 22082213.
40 J. C. Otamiri, S. L. T. Andersson and A. Andersson, Appl. Catal., 1990, 65, 159-174.

41 S. Poulston, P. M. Parlett, P. Stone and M. Bowker, Surf. Interface Anal., 1996, 24, 811-820.

42 M. Richter, M. Fait, R. Eckelt, M. Schneider, J. Radnik, D. Heidemann and R. Fricke, J. Catal., 2007, 245, 11-24.

43 A. Wollner, F. Lange, H. Schmelz and H. Knozinger, Appl. Catal., A, 1993, 94, 181-203.

44 S. S. Maluf, P. A. P. Nascente, C. R. M. Afonso and E. M. Assaf, Appl. Catal., A, 2012, 413-414, 85-93.

45 A. Boisen, T. V. W. Janssens, N. Schumacher, I. Chorkendorff and S. Dahl, J. Mol. Catal. A: Chem., 2010, 315, 163-170.

46 É. Gaudry, A. K. Shukla, T. Duguet, J. Ledieu, M.-C. DeWeerd, J.-M. Dubois and V. Fournée, Phys. Rev. B: Condens. Matter Mater. Phys., 2010, 82, 085411.

47 J. Li, Z. Yang, T. Wang, N. Yu, L. Sun, C. Nie, H. Teng, C. Jin, X. Chen and H. Geng, RSC Adv., 2015, 5, 75044-75054. 